\title{
ANALISIS PENGGUNAAN PERSAMAAN MULTICHANNEL SEA SURFACE TEMPERATUR (MCSTT) SPLIT-WINDOW PADA SENSOR SATELIT NOAA-AVHRR UNTUK DETEKSI TEMPERATUR PERMUKAAN AIR LAUT
}

\section{Analysis Of Multichannel Sea Surface Temperature Equation (MCSTT) Split-Window On NOAA-AVHRR Satellite Sensor For Detection Of Sea Surface Temperature}

\author{
Agung Mulyo Widodo, agung.mulyo@esaunggul.ac.id ${ }^{1)}$, Nizirwan Anwar, \\ nizirwan.anwar@esaunggul.ac.id ${ }^{2}$ \\ 1)2) Teknik Informatika / Fakultas IImu Komputer, Universitas Esa Unggul
}

\begin{abstract}
Sea surface temperatures have a great influence on weather conditions and terrestrial climates. The phenomena that occur in the oceans such as La Nina and El Nino also have a great impact on the changing world weather. For that required data of sea surface temperature up to date. The remote sensing technology can be used to monitor up-to-date seawater temperatures using NOAA's AVHRR-

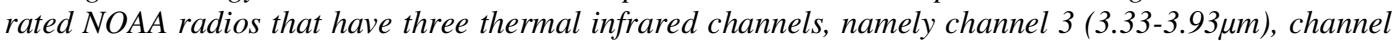

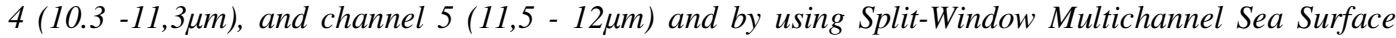
Temperature (MCSTT) to calculate sea surface temperature. In this research will be an analysis of the accuracy of the use of these equations for tropical perariran in Indonesia. Field verification performed on the coast in Tuban region with geographical coordinates $\left(6.83099^{\circ}-6.76149^{\circ}\right.$ SL and $112,029^{\circ}$ $\left.112,101^{\circ} E L\right)$ by measuring the temperature at 30 points for comparison. The results of these measurements are then tested statistics Kolmogorov-Smirnov test and the results of temperature data obtained from the calculation and measurement of both normal distribution then because the normal distribution is done t test with 95\% confidence level to compare between the temperature obtained from the calculation by using the value gray pixels with temperature measurements in the field turned out the average population is not the same or different significantly and the difference between the temperature shown image with temperature measurement results of $0.9886{ }^{\circ} \mathrm{C}$
\end{abstract}

Keywords: Remote Sensing, NOAA, AVHRR Sensor, Multichannel Surface Temperature (MCSTT) SplitWindow equation

\begin{abstract}
ABSTRAK
Temperatur permukaan air laut mempunyai pengaruh yang besar pada kondisi cuaca dan iklim daratan. Fenomena-fenomena yang terjadi di lautan seperti La Nina dan El Nino juga mempunyai dampak yang besar pada berubahnya cuaca dunia. Untuk itu diperlukan data temperatur permukaan air laut secara up to date. Teknologi remote sensing dapat digunakan untuk memonitor temperatur permukaan air laut secara up to date dengan menggunakan wahana satelit yaitu NOAA yang memiliki sensor AVHRR yang mempunyai tiga saluran inframerah termal yaitu saluran $3(3,33-3,93 \mu \mathrm{m})$, saluran $4(10,3-11,3 \mu \mathrm{m})$, dan saluran 5(11,5 - 12 $\mu \mathrm{m})$ dan dengan menggunakan persamaan Multichannel Sea Surface Temperatur (MCSTT) Split-Window untuk melakukan perhitungan temperatur permukaan air laut. Dalam penelitian ini akan dilakukan analisis terhadap keakuratan penggunaan persamaan tersebut untuk perariran tropis di Indonesia. Verifikasi di lapangan yang dilakukan pada pantai di wilayah Tuban dengan koordinat geografis $\left(6,83099^{\circ}-6,76149^{\circ}\right.$ LS dan $\left.112,029^{\circ}-112,101^{\circ} \mathrm{BT}\right)$ dengan melakukan pengukuran suhu di 30 titik sebagai perbandingan. Hasil pengukuran tersebut kemudian dilakukan uji statistika yaitu uji Kolmogorov-Smirnov dan hasilnya data temperatur baik yang didapat dari perhitungan maupun pengukuran keduanya berdistribusi normal kemudian karena berdistribusi normal dilakukan uji t dengan tingkat kepercayaan` 95\% untuk membandingkan antara temperatur yang didapatkan dari perhitungan dengan mempergunakan nilai keabuan piksel dengan temperatur pengukuran di lapangan ternyata rata-
\end{abstract}


rata populasinya tidak sama atau berbeda secara nyata dan selisih antara temperatur yang ditunjukkan citra dengan temperatur hasil pengukuran sebesar $0,9886{ }^{\circ} \mathrm{C}$.

Kata Kunci: Remote Sensing, NOAA, Sensor AVHRR, persamaan Multichannel Sea Surface Temperatur (MCSTT) Split-Window

\section{PENDAHULUAN}

Sekitar $70 \%$ luas permukaan bumi terdiri dari lautan, Indonesia sekitar $80 \%$ wilayahnya terdiri atas lautan. Selain merupakan bagian yang terluas dari permukaan bumi, temperatur permukaan air laut mempunyai pengaruh yang besar pada kondisi cuaca dan iklim di daratan. Pengamatan temperatur permukaan air laut sangat penting dalam bidang meterologi dan bidang climical karena besarnya pengaruh yang disebabkan oleh temperatur permukaan air laut. Maka sangatlah penting untuk mengetahui temperatur permukaan air laut secara up to date. Pengukuran temperatur permukaan air laut dapat dilakukan dengan menggunakan teknologi remote sensing dengan menggunakan wahana satelit. Salah satu satelit yang dapat digunakan untuk pengamatan temperatur permukaan air laut adalah NOAA (National Oceanic Atmospheric Administration). NOAA mempunyai sensor AVHRR (The Advanced Very High Resolution Radiometer). AVHRR ini mempunyai 3 saluran inframerah termal yang dapat digunakan untuk mengukur temperatur permukaan air laut. tiga saluran inframerah termal tersebut adalah saluran 3 (3,55-3,93 $\mu \mathrm{m})$, saluran $4(10,3-11,3 \mu \mathrm{m})$ dan saluran $5(11,5-12,5 \mu \mathrm{m})$.

Berdasarkan dari sensor-sensor yang ada di satelit NOAA diatas, maka satelit NOAA dapat digunakan untuk mengetahui temperatur permukaan laut dalam cakupan yang luas melalui informasi yang diperoleh dari sensor-sensor termal satelit tersebut dan diolah dengan formula tertentu. Salah satunya adalah penerapan persamaan Multichannel Sea Surface Temperature (MCSTT) Split-Window yang menggunakan saluran inframerah termal empat $(10,3$ - 11,3 $\mu \mathrm{m})$ dan lima $(11,5$ 12,5 $\mu \mathrm{m})$. Sejauh mana kedua saluran inframerah termal tersebut peka terhadap perbedaan temperatur permukaan air laut dan apakah formula tersebut dapat digunakan untuk perairan tropis khususnya di Indonesia menarik peneliti untuk melakukan analisis terhadap penerapan penggunan persamaan tersebut merupakan permasalahan yang dimbil ada penelitian ini.

Tujuan dari penelitian ini adalah melakukan analisis sejauh mana kedua saluran inframerah termal pada AVHRR saluran inframerah termal peka terhadap perbedaan temperatur permukaan air laut dan dapat digunakan di perairan tropis khususnya Indonesia.

Ada beberapa batasan masalah yang perlu diperhatikan, pda penelitian ini yakni:

- Pengambilan data didasarkan pada saat keadaan cuaca yang normal dan tidak terdapat gangguan alam.

- Citra yang digunakan adalah citra

- NOAA AVHRR yang sudah terkoreksi secara radiometris maupun geometris.

- Daerah penelitian terletak di Tuban dengan koordinat geografis $6,83099^{\circ}-$ $6,76149^{\circ}$ Lintang Selatan dan $112.029^{\circ}$ $-112,101^{\circ}$ Bujur Timur.

Penginderaan jauh ialah ilmu dan seni untuk memperoleh informasi tentang obyek, daerah, atau gejala dengan jalan menganalisa data yang diperoleh dengan menggunakan alat tanpa kontak langsung terhadap obyek, daerah, atau gejala yang dikaji (Lillesand dan Kiefer, 1979). Alat yang dimaksud adalah alat pengindera atau sensor yang pada umumnya dipasang pada wahana yang berupa pesawat terbang, satelit, pesawat ulak-alik. Penginderaannya dilakukan dari jarak jauh sehingga disebut penginderaan jauh.

Tujuan utama penginderaan jauh adalah mengumpulkan data sumber daya alam dan lingkungan. Informasi tentang obyek disampaikan ke pengamat melalui energi elektromagnetik. Penginderaan jauh 
meliputi dua proses utama yaitu: (1) subsistem perolehan data, dan (2) subsistem analisis atau sintesis

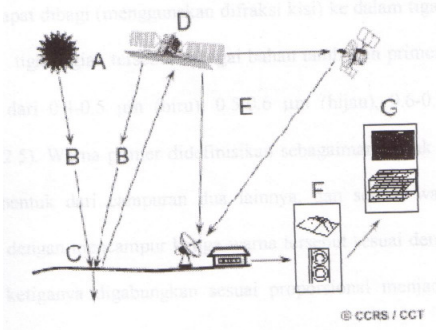

\section{Gambar 1. Proses Penginderaan Jauh ${ }^{[7]}$}

Berdasarkan Gambar 1, berikut ini keterangan gambar :

- Sumber energi atau illuminasi

- Radiasi dan atmosfer

- Interaksi dan sasaran

- Rekaman dari energi dengan menggunakan sensor

- Tranmisi, penerimaan, dan pemrosesan

- Interpretasi dan analisis

- Aplikasi

\section{Subsistem Perolehan Data}

Subsistem perolehan data terdiri atas : (1) tenaga, (2) objek atau benda sebagai masukan (input), (3) proses, dan (4) keluaran (output).

Tenaga dalam penginderaan jauh digunakan tenaga elektromagnetik, yaitu tenaga yang bergerak dengan kecepatan cahaya (3.108 meter/detik) dengan pola gelombang sinusoida yang harmonis (Sabins,Jr.,1986). Radiasi elektromagnetik merupakan salah satu tenaga dinamik yang tampak bila ia berinteraksi dengan benda. Radiasi elektromagetik dapat berbentuk gelombang maupuin dalam bentuk partikel.

\section{Objek atau benda sebagai masukan (input)}

Objek penginderaan jauh dapat berupa benda (air, tanah, bangunan, vegetasi) atau fenomena atmosfer maupun di permukaan bumi (temperatur udara, kecepatan angin, erosi, distribusi rumah mukim). Berbeda dengan benda yang tampak pada gambar / rekaman, fenomena dapat dikenali melalui benda terkait.

\section{Proses}

Proses di dalam subsistem perolehan data dibedakan atas (a) interaksi antara tenaga dan atmosfer, (b) interaksi antara tenaga dan obyek, dan (c) perekaman.

\section{Interaksi antara tenaga dan atmosfer}

Tanpa memperlihatkan sumbernya, semua radiasi yang dideteksi dengan system penginderaan jauh tentu melalui atmosfer dengan jarak atau panjang jalur tertentu. Tanpa memperlihatkan sumbernya, semua radiasi yang dideteksi dengan system penginderaan jauh tentu melalui atmosfer dengan jarak atau panjang jalur tertentu.

Atmosfer mengandung molekul gas dan partikel aerosol seperti butiran kecil air, debu dan asap yang menimbulkan pancaran dan absorpsi energi elektromagnetik. Pengaruh ini terutama disebabkan oleh mekanisme hamburan (scattering) dan serapan (absorption) atmosferik. Hamburan akan menyebabkan perubahan arah dan intensitas radiasi. Hal ini bergantung pada panjang gelombang. Pada umumnya pancaran akan berkurang dengan meningkatnya radiasi panjang gelombang.

\section{Interaksi antara tenaga dan obyek}

Apabila tenaga elektromagnetik mengenai suatu permukaan di muka bumi, terdapat tiga kemungkinan pokok interaksi tenaga dengan benda di permukaan bumi. Sebagian energi direfleksikan (bila bendanya pejal/solid) dan sisanya akan masuk ke benda sebagai gelombang depan yang direfraksi yang juga diserap atau dretensi oleh benda itu, atau ditransmisikan melalui kenampakan tersebut, bergantung pada sifat benda yang membentuk perwujudan dan panjang gelombangnya.

Interaksi antara tenaga elektromagnetik dengan benda di permukaan bumi ditunjukkan pada gambar 2 , 


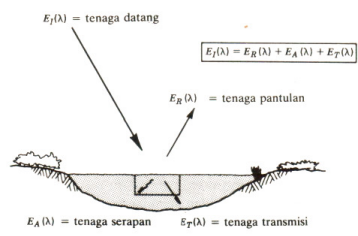

\section{Gambar 2. Interaksi antara tenaga elektromagnetik dengan benda di permukaan bumi ${ }^{[6]}$.}

Dalam interaksi antara tenaga dan benda, ada dua hal penting yang perlu diperhatikan (Lillesand, Kiefer 1979), yaitu

Besarnya tenaga yang dipantulkan, diserap dan ditransmisikan akan berbeda untuk objek di muka bumi yang berbeda, tergantung jenis materi dan kondisinya (umur, musim, kelembaban, dsb). Perbedaan ini memungkinkan kita untuk membedakan objek yang berbeda pada suatu citra.

Besarnya tenaga yang dipantulkan, diserap, dan ditransmisikan bagi satu jenis benda berbeda-beda menurut panjang gelombangnya.

Perekaman objek di dalam penginderaan jauh dapat dilakukan secara serempak untuk seluruh daerah yang terekam pada suatu lembar gambar. Dapat pula dilakukan bagian demi bagian dengan cara penyiaman (scanning)

Keluaran subsistem perolehan data di dalam sistem penginderaan jauh ialah data penginderaan jauh. Sesuai dengan cara perekamannya maka data penginderaan jauh dapat berupa (1) data digital maupun (2) data analog (visual, gambar)

Data digital penginderaan jauh terekam dalam bentuk angka yang menunjukkan nilai kecerahan (tingkat keabuan). Angka tersebut menunjukkan nilai kecerahan bagi tiap sel kecil yang disebut pixel (picture element), yakni ukuran terkecil objek yang dapat direkam oleh suatu sensor. Oleh karena itu maka angka ini sering disebut nilai pixel atau nilai digital. Nilai pixel dapat dibuat berkisar antara $1-63 ; 0-127$ atau $0-225$.
Data visual penginderaan jauh yang direkam dalam bentuk gambar. Data visual ini dibedakan atas data visual satu dimensional (garis / grafik) dan data visual data dua dimensional (citra).

Tenaga yang datang dari obyek di permukaan bumi diterima dan direkam oleh sensor. Sensor penginderaan jauh adalah bagian penting karena bagian ini yang mampu menyadap informasi yang diindera. Tiap sensor mempunyai kepekaan diri terhadap bagian spektrum elektromagnetik.

Berdasarkan proses perekamannya, sensor dibedakan atas :

- Sensor fotografik

Pada sensor fotografik, proses perekamannya berlangsung dengan cara kimiawi. Tenaga elektromagnetik diterima dan direkam pada lapisan emulsi film yang bila diproses akan menghasilkan foto. Jadi, dalam proses ini film berfungsi sebagai penerima tenaga dan sekaligus sebagai alat perekamannya.

Sensor fotografik hanya peka terhadap spektrum tampak $(0,4 \mu \mathrm{m}-0,7$ $\mu \mathrm{m})$, spektrum ultraviolet dekat $(0,3 \mu \mathrm{m}$ $-0,4 \mu \mathrm{m})$ dan spektrum inframerah dekat $(0,7 \mu \mathrm{m}-0,9 \mu \mathrm{m})$.

- Sensor elektronik

Pada sensor elektronik menggunakan tenaga elektrik dalam bentuk sinyal elektrik. Alat penerima dan perekamnya berupa pita magnetic atau detector lainnya, bukan film. Sinyal elektrik direkam pada pita magnetic ini kemudian dapat diproses menjadi data visual maupun data digital yang siap dikomputerkan. Sensor elektonik lebih besar kepekaannya, yakni meliputi spektrum tampak, spektum ultraviolet dekat, spektrum inframerah dekat, spektrum inframerah termal, dan spektrum gelombang mikro.

Sedangkan menurut energi yang dipakai, sensor yang digunakan dalam satelit penginderaan jauh dapat dibedakan menjadi dua, yaitu : 
- Sensor pasif (sensor optis)

Sensor pasif adalah sensor yang dalam penggunaannya dipenginderaan jauh menggunakan tenaga berupa gelombang elektromagnetik dari alam atau berdasarkan objek yang diamati seperti kamera (daerah sinar tampak dan inframerah dekat), scanner dan radiometer (daerah tampak, inframerah dekat dan termal).

- Sensor aktif (sensor radar)

Sensor aktif adalah jenis sensor yang dalam penggunaannya dipengiinderaan jauh menggunakan tenaga berupa gelombang elektromagnetik buatan seperti yang digunakan oleh radar (daerah gelombang mikro) dan laser profiler, gelombang yang dibuat dipancarkan kesasaran kemudian sasaran tersebut memantulkannya kembali sehingga terdeteksi lagi oleh radar.

\section{Satelit NOAA}

NOAA adalah bagian dari seriseri satelit cuaca milik US. Pengoperasian sistem negara-negara yang berhubungan dengan satelit lingkungan (cuaca) adalah salah satu tanggung jawab terbesar dari NOAA's National Environmental Satellite, Data, and Information Service (NESDIS). NESDIS mengoperasikan satelit-satelit dan mengatur pemorsesan dan distribusi dari berjuta-juta bit data dan image-image yang dihasilkan satelit-satelit tersebut per hari. NOAA mengoperasikan dua macam satelit penginderaan jauh, yaitu satelit yang mempunyai orbit geostationary dan yang mempunyai orbit polar. Satelit NOAA 14 merupakan satelit yang mempunyai orbit polar NOAA mengoperasikan dua macam satelit penginderaan jauh, yaitu satelit yang mempunyai orbit geostationary dan yang mempunyai orbit polar. Satelit NOAA 14 merupakan satelit yang mempunyai orbit polar. Orbit yang berbentuk polar memungkinkan dapat memonitor seluruh bagian bumi.

Satelit NOAA yang mempunyai bentuk orbit polar, dengan attitude antara
$830 \mathrm{~km}$ (orbit pagi) dan $870 \mathrm{~km}$ (orbit sore), dan merupakan sun synchronous. Satu satelit menyebrangi daerah ekuator pada pukul 7:30 a.m. waktu setempat, dan yang lainnya pada 1:40 p.m waktu setempat

Informasi orbital NOAA 14 dapat dilihat pada tabel 1 dibawah ini:

Tabel 1. Informasi orbital NOAA $14^{[1]}$

\begin{tabular}{ll}
\hline Tanggal launching & 30 Desember 1994 \\
\hline Type & Sun synchronous \\
Altitude & $808 \mathrm{~km}$ \\
Periode & $101.2 \mathrm{menit}$ \\
Inclination angle & 98.6 derajat \\
Precession rate & $-1.8 \mathrm{~min} / \mathrm{month}$ \\
\hline
\end{tabular}

NOAA mengelilingi bumi pada orbitnya dua kali dalam sehari. Nominal instrumen spasial resolusi kira - kira 1,1 km. $1.1 \mathrm{~km}$ data 'HRPT' merupakan menyiarkan kepada setiap daerah penerima pada daerah tampilan antena pengiriman.

Sensor yang paling utama yang digunakan oleh NOAA adalah AVHRR. AVHRR mempunyai 5 saluran yang mempunyai range $0.58-1.10 \mu \mathrm{m}$ untuk saluran $1,0.725-1.10 \mu \mathrm{m}$ untuk saluran $2,3.55-3.93 \mu \mathrm{m}$ untuk saluran $3,10.3-$ $11.3 \mu \mathrm{m}$ untuk saluran 4 , dan $11.5-12.5$ $\mu \mathrm{m}$ untuk saluran 5 dan karataeristik tiaptiap saluran ditunjukkan pada Tabel 2 .

Tabel 2. Karakteristik Tiap Band ${ }^{[6]}$

\begin{tabular}{|l|l|l|}
\hline Saluran & $\begin{array}{c}\text { Panjang } \\
\text { Gelombang, } \\
\boldsymbol{\mu m}\end{array}$ & \multicolumn{1}{|c|}{ Karakteristik Saluran } \\
\hline 1 & $0,580-0,68$ & $\begin{array}{l}\text { Awan pada siang hari, salju, } \\
\text { es, dan pemetaan vegetasi. }\end{array}$ \\
\hline 2 & $0,725-1,10$ & $\begin{array}{l}\text { Pengambaran permukaan air- } \\
\text { tanah, salju, es, dan pemetaan } \\
\text { vegetasi }\end{array}$ \\
\hline 3 & $3,55-3,93$ & $\begin{array}{l}\text { Memonitor target-target } \\
\text { panas (gunung-gunung } \\
\text { berapi, kebakaran hutan, } \\
\text { pemetaan awan pada malam } \\
\text { hari }\end{array}$ \\
\hline 5 & $10,30-11,30$ & $\begin{array}{l}\text { Awan pada siang dan malam } \\
\text { hari dan pemetaan temperatur } \\
\text { permukaan air laut }\end{array}$ \\
\hline & $\begin{array}{l}\text { Awan dan temperatur } \\
\text { permukaan air laut, dan } \\
\text { pemetaan awan pada siang } \\
\text { dan malam hari }\end{array}$ \\
\hline
\end{tabular}




\section{Temperatur Permukaan Air Laut}

Pada bidang kelautan data AVHRR

paling berfungsi digunakan untuk menentukan temperatur permukaan air laut dengan menggunakan data dari saluran inframerah termal.

Salah satu faktor penting dalam mengetahui cuaca laut adalah interaksi yang terjadi pada udara permukaan laut, terutama termasuk fenomena yang terjadi yang mana ada perpindahan energi antara air dan udara yang ada misalnya, kondensasi, evaporasi, radiasi, hujan dll. Model prediksi cuaca yang berhasil harus meliputi semua mekanisme perpindahan energi pada skala global.

\section{METODE PENELITIAN}

Rangkaian kegiatan untuk menguraikan tentang bahan atau alat penelitian, ,jalan penelitian, dijelaskan di bawah ini. Dalam menjabarkan suatu informasi dari suatu citra, yang perlu diperhatikan pertama kali adalah jenis citra yang digunakan.

Pada proses perhitugan temperatur permukaan air laut ini citra yang digunakan adalah citra NOAA 14 yang menggunakan AVHRR sebagai salah satu sensornya dengan spesifikasi sebagai berikut :

a. Saluran / band satu $(0,58-0,68$ $\mu \mathrm{m})$

b. Saluran / band dua $(0,725-1,10$ $\mu \mathrm{m})$

c. Saluran / band tiga $(3,55-3,93$ $\mu \mathrm{m})$

d. Saluran / band empat (10,30 $11,30 \mu \mathrm{m})$

e. Saluran / band lima $(11,50-12,50$ $\mu \mathrm{m})$

Kemudian citra yang digunakan mempunyai spesifikasi sebagai berikut :

- Tanggal pemotretan: 10 Mei 2017

- Tipe data : Raster

- Format : Er-Mapper

- Jumlah baris : 1617

- Jumlah sel per baris : 1111

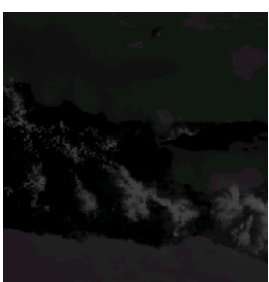

(a)

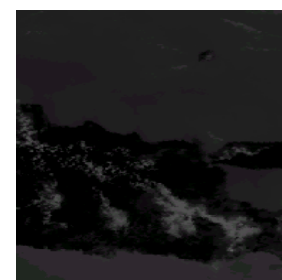

(b)
Gambar 3. (a) Citra saluran 4 (b) Citra saluran 5

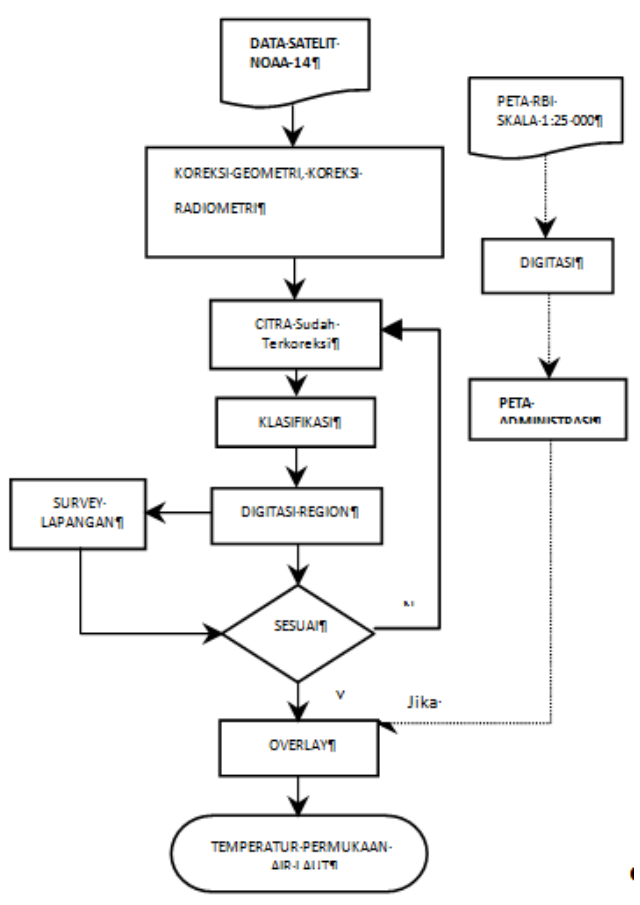

Gambar 4. Diagram alir jalan penelitian

Data citra yang digunakan untuk mengukur temperatur permukaan air laut adalah data citra band 4 dan band 5 karena berdasarkan pada hukum pergeseran Wien dan pada pada kurva radiasi pancaran spectral benda hitam sempurna pada pelbagai suhu terlihat bahwa pada panjang gelombang sekitar 9,7 - $14 \mu \mathrm{m}$ permukaan bumi (tanah, vegetasi, air) yang suhu rataratanya $300^{\circ} \mathrm{K}$ memancarkan radiasi maksimum dan panjang gelombang band 4 $(10,30-11,30 \mu \mathrm{m})$ dan band $5(11,50-$ $12,50 \mu \mathrm{m})$ termasuk dalam range panjang gelombang dimana permukaan bumi memancarkan radiasi maksimum serta band 
4 mempunyai range pengukuran -100 hingga $57^{\circ} \mathrm{C}$ dan band 5 mempunyai range pengukuran -105 hingga $+50^{\circ} \mathrm{C}$ diyakini dapat digunakan untuk mengukur temperatur permukaan air laut. Data citra yang digunakan dapat dilihat pada Gambar 3.

Dalam penelitian ini meliputi
beberapa tahapan proses. Proses pengolahan citra pada penelitian ini, secara garis besarnya mengikuti tahapan penentuan daerah penelitian pada citra NOAA-14, proses pengolahan data, penentuan titik-titik pengukuran temperatur permukaan air laut berdasarkan koordinat tiap perbedaan kelas pengolahan citra, penentuan keterkaitan antara data citra dengan data hasil pengukuran, serta layout citra dengan perbedaan temperatur permukaan air laut yang diwakili dengan perbedaan rona pada daerah laut. Langkahlangkah pengerjaan data dalam penelitian ini secara garis besarnya dapat dilihat pada diagram alir (gambar 4)

Penggolahan data citra dilakukan dengan menggunakan bantuan software Ermapper, Arc View dan Map Info. Survei di lapangan dilakukan untuk mengetahui temperatur yang sebenarnya di lapangan yang akan digunakan sebagai pembanding dari temperatur yang di tampilakan oleh citra. Jalannya survey adalah sebagai berikut :

- Mempersiapkan dan melakukan pengecekkan kondisi perlengkapan yang akan digunakan untuk melakukan survey

- Setibanya di lapangan sebelum menaiki kapal terlebih dahulu mempersiapkan GPS guna mendapatkan sinyal yang baik dari satelit pemancar.

- Memberitahu prosedur pengambilan data kepada pemilik kapal dan meminta saran pengambilan data dilakukan pada titik survey yang mana dulu mengingat pemilik kapal lebih menggetahui keadaan medan.

- Menaiki perahu dan menuju titik survey dengan menggunakan bantuan GPS agar dapat melakukan pengukuran tepat pada titik survey yang dimaksud.
- Setelah sampai pada titik survey yang dimaksud pengukuran temperatur dimulai. Probe termometer dimaksukkan kedalam laut, ditunggu hingga tampilan pada termometer stabil kemudian dicatat pada tabel survey yang telah disiapkan sebelumnya. Ada 30 titik survey. Tiap titik survey dilakukan pengukuran lima (5) kali., dan pada tiap titik survey juga dilakukan hal yang sama. Setelah mendapat temperatur permukaan air laut dari lima kali pengukuran data yang digunakan untuk mewakili temperatur pada titik survey adalah rata-rata dari pengukuran temperatur pada titik tersebut

- Setelah semua titik survey telah diukur temperaturnya maka survey selesai dan perahu kembali ke daratan.

\section{HASIL DAN PEMBAHASAN}

Terdapat 30 titik pengambilan data dan tiap titik pengambilan data dilakukan lima kali pengukuran dan data temperatur yang yang digunakan sebagai acuan adalah temperatur rata-rata hasil pengukuran.

Perhitungan temperatur permukaan air laut dengan menggunakan data dari AVHRR. menggunakan persamaan MCSTT split-window yang ditetapkan oleh NOAA/NESDIS. MCSST merupakan kata lain dari Multichannel Sea Surface Temperatur, sedangkan split-window mengindikasikan menggunakan data dari saluran 4 dan saluran 5, persamaan MCSST yang didapat dari website milik Australian Government, Bureau of Meteorology pada www.Bureau.com ditunjukkan Rumus (1). Untuk NOAA-14

$$
\begin{aligned}
& \text { MCSST Day Split Window }{ }^{[12]}: \\
& \begin{aligned}
\text { Sst }= & \left(1,017342 * \mathrm{~T}_{4}\right)+\left(2,139588 *\left(\mathrm{~T}_{4}-\right.\right. \\
& \left.\mathrm{T}_{5}\right)+0,779706 *\left(\mathrm{~T}_{4}-\mathrm{T}_{5}\right) *(\mathrm{sec} \\
& (\mathrm{ZA})-1)+(-278,43)+273,16 \ldots \ldots .(1)
\end{aligned}
\end{aligned}
$$

dimana :

Sst : nilai sst dalam ${ }^{\circ} \mathrm{C}$

$\mathrm{T}_{4} \quad$ : temperatur pada band 4

$\mathrm{T}_{5}$ : temperatur pada band 5

$\mathrm{ZA}$ : solar zenith angle $\left(70,66^{\circ} \mathrm{C}\right)$ 
Tabel 3. Perbandingan nilai temperatur antara perhitungan dari nilai keabuan dengan pengukuran di lapangan.

\begin{tabular}{|c|c|c|}
\hline Titik & $\begin{array}{c}\text { Temperatur } \\
\text { perhitungan }{ }^{\circ} \mathrm{C}\end{array}$ & $\begin{array}{c}\text { Temperatur } \\
\text { pengukuran }{ }^{\circ} \mathrm{C}\end{array}$ \\
\hline 1 & 27,62 & 28,66 \\
\hline 2 & 27,69 & 28,74 \\
\hline 3 & 25,39 & 26,44 \\
\hline 4 & 25,48 & 26,9 \\
\hline 5 & 27,24 & 28,44 \\
\hline 6 & 26,14 & 27,34 \\
\hline 7 & 27,76 & 28,74 \\
\hline 8 & 27,06 & 28,1 \\
\hline 9 & 23,54 & 26,54 \\
\hline 10 & 26,50 & 27,4 \\
\hline 11 & 27,33 & 28,44 \\
\hline 12 & 25,40 & 26,42 \\
\hline 13 & 28,67 & 29,24 \\
\hline 14 & 26,53 & 27,42 \\
\hline 15 & 28,7 & 29,26 \\
\hline 16 & 28,7 & 29,26 \\
\hline 17 & 27,65 & 28,72 \\
\hline 18 & 27,65 & 28,74 \\
\hline 19 & 27,86 & 28,82 \\
\hline 20 & 27,34 & 28,48 \\
\hline 21 & 26,60 & 27,46 \\
\hline 22 & 26,83 & 27,74 \\
\hline 23 & 27,34 & 28,54 \\
\hline 24 & 27,57 & 28,64 \\
\hline 25 & 27,57 & 28,64 \\
\hline 26 & 27,20 & 28,14 \\
\hline 27 & 27,20 & 28,14 \\
\hline 28 & 26,76 & 27,72 \\
\hline 29 & 26,70 & 27,52 \\
\hline 30 & 27,57 & 28,64 \\
\hline
\end{tabular}

Kemudian tiap-tiap data temperatur yang di dapat dari perhitungan dengan menggunakan MCSST dan dari pengukuran dilapangan di uji dengan uji KolmogorovSmirnov untuk mengetahui distribusi data temperatur apakah berdistribusi normal atau tidak. Uji ini dilakukan dengan menggunakan bantuan SPSS 11 .

\section{Uji Kolmogorov-Smirnov, dengan tingkat kepercayaan 95\%}

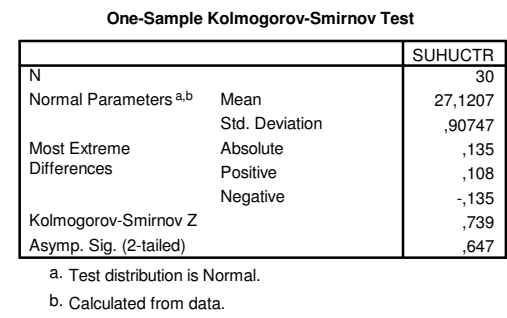

- Temperatur permukaan air laut dari perhitungan MCSST

\section{Hipotesis.}

$\mathrm{H}_{\mathrm{o}}: \mathrm{F}(\mathrm{x})=\mathrm{F}_{\mathrm{o}}(\mathrm{x})$, dengan $\mathrm{F}(\mathrm{x})$ adalah fungsi distribusi populasi yang diwakili oleh sample, dan $\mathrm{F}_{\mathrm{o}}(\mathrm{x})$ adalah fungsi distribusi populasi berdistribusi normal dengan $\mu$ (mean populasi) $=27,1207$ dan $\sigma$ (standart deviasi) $=0,90747$

$\mathrm{H}_{1}: \mathrm{F}(\mathrm{x}) \neq \mathrm{F}_{\mathrm{o}}(\mathrm{x})$ atau distribusi populasi tidak normal

\section{Pengambilan Keputusan}

- Jika probabilitas . > 0,05, maka $\mathrm{H}_{\mathrm{o}}$ diterima

- Jika probabilitas $<0,05$, maka $\mathrm{H}_{\mathrm{o}}$ ditolak Keputusan :

- Terlihat bahwa pada kolom asymp.Sig/asymptotic significane dua sisi adalah 0,647, atau diatas 0,05 $(0,647$ $>$ 0,05). Maka $\mathrm{H}_{\mathrm{o}}$ diterima atau distribusi populasi temperatur dari perhitungan adalah normal

- Temperatur permukaan air laut dari pengukuran dilapangan

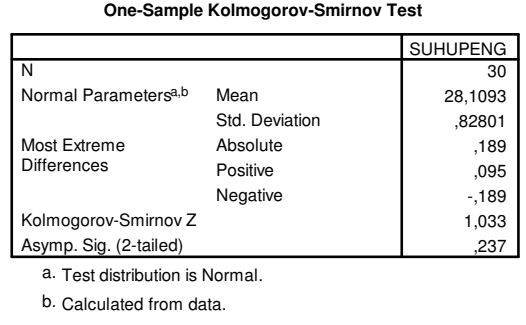

\section{Hipotesis.}

$\mathrm{H}_{\mathrm{o}}: \mathrm{F}(\mathrm{x})=\mathrm{F}_{\mathrm{o}}(\mathrm{x})$, dengan $\mathrm{F}(\mathrm{x})$ adalah fungsi distribusi populasi yang diwakili oleh sample, dan $\mathrm{F}_{\mathrm{o}}(\mathrm{x})$ adalah fungsi distribusi populasi berdistribusi normal dengan $\mu=28,1093$ dan $\sigma=$ 0,82801

$\mathrm{H}_{1}: \mathrm{F}(\mathrm{x}) \neq \mathrm{F}_{\mathrm{o}}(\mathrm{x})$ atau distribusi populasi tidak normal 


\section{Pengambilan Keputusan}

- Jika probabilitas . > 0,05, maka $\mathrm{H}_{\mathrm{o}}$ diterima

- Jika probabilitas $<0,05$, maka $\mathrm{H}_{\mathrm{o}}$ ditolak

\section{Keputusan :}

- Terlihat bahwa pada kolom asymp.Sig/asymptotic significane dua sisi adalah 0,237 atau diatas $0,05(0,237$ $>$ 0,05). Maka $\mathrm{H}_{\mathrm{o}}$ diterima atau distribusi populasi temperatur dari perhitungan adalah normal

Dari pengujian yang telah dilakukan pada kedua data temperatur di dapat bahwa data yang di dapat dari perhitungan dengan data yang didapat dari pengukuran kedua mempunyai distribusi normal, karena kedua datanya terdistribusi normal maka dilakukan Uji t. Uji t dilakukan untuk mengambil keputusan atau perkiraan tentang populasi temperatur berdasarkan informasi yang terkandung dari sample yang ada.

\section{Uji t Output SPSS dan Analisis :}
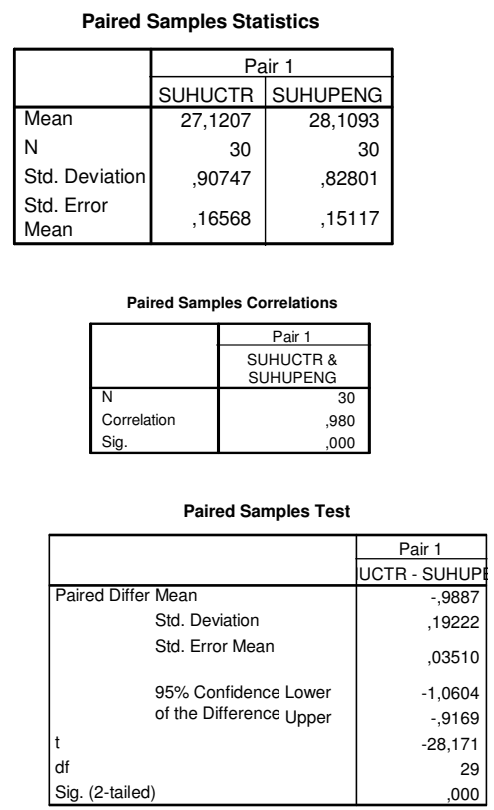

Analisis :

\section{Output Bagian Pertama (Group Statistics).}

Untuk temperatur yang didapat dari perhitungan mempunyai temperatur ratarata $27,1207{ }^{\circ} \mathrm{C}$, sedangkan temperatur yang didapat dari pengukuran di lapangan mempunyai rata-rata $28,1093{ }^{\circ} \mathrm{C}$.

\section{Output Bagian Kedua (Group Statistics).}

Korelasi antara kedua variable yang menghasilkan angka 0,980 dengan nilai probabilitas jauh di bawah 0,05 yaitu 0,000 . Ini menyatakan bahwa korelasi antara temperatur dari hasil perhitungan dan hasil pengukuran di lapangan adalah sangat erat dan benar-benar berhubungan secara nyata.

\section{Output Bagian Ketiga (Paired Sample Test)}

\section{Hipotesis}

$\mathrm{H}_{\mathrm{o}}$ : Kedua rata-rata Populasi adalah identik $\mathrm{H}_{1}$ : Kedua rata-rata Populasi tidak identik

\section{Pengambilan Keputusan}

a. Berdasarkan perbandingan $t$ hitung dengan $\mathrm{t}$ table (dasar pengambilan keputusan sama dengan uji t):

- Jika Statistik Hitung (angka t output) > Statistik Tabel (liat tabel), maka $\mathrm{H}_{\mathrm{o}}$ ditolak

- Jika Statistik Hitung (angka t output) < Statistik Tabel (tabel t), maka $\mathrm{H}_{\mathrm{o}}$ diterima.

Hasil t, hitung dari output adalah -28,171, sedangkan dari tabel t didapat angka 1,699

b. Berdasarkan nilai Probabilitas

- Jika probabilitas > 0,05, maka $\mathrm{H}_{\mathrm{o}}$ diterima

- Jika probabilitas < 0,05, maka $\mathrm{H}_{\mathrm{o}}$ dittolak

\section{Keputusan}

○ Terlihat bahwa t hitung adalah $-28,171$ dengan probabilitas 0,000 . Oleh karena probabilitas $<0,05$, maka $\mathrm{H}_{\mathrm{o}}$ ditolak. 
Artinya temperatur permukaan air laut yang didapat dari perhitungan berbeda dengan kata lain kedua rata-rata Populasi tidak identik(berbeda secara nyata)

- Terdapat perbedaan Mean sebesar 0,9886 , angka ini didapat dari

Mean temperatur pengukuran - mean temperatur perhitungan,

$\underset{0,9886{ }^{\circ} \mathrm{C}}{\text { Atau }} 28,1093{ }^{\circ} \mathrm{C}-27,1207{ }^{\circ} \mathrm{C}=$

\section{Analisis Teknis}

Temperatur permukaan air laut yang di dapatkan dari perhitungan dengan hasil pengukuran di lapangan terjadi perbedaan mean sebesar $0,9886{ }^{\circ} \mathrm{C}$. Hal ini disebabkan oleh beberapa faktor antara lain temperatur lingkungan sekitarnya yang disebabkan kondisi cuaca, banyaknya energi matahari yang diterima oleh permukaan air laut, dan banyaknya angin yang bertiup. Cuaca mendung dengan cerah sudah membedakan energi matahari karena matahari terhalang oleh mendung. Banyaknya energi matahari yang diterima oleh permukaan air laut menyebabkan banyaknya energi matahari yang diserap dan di emisikan oleh permukaan air laut sehingga temperatur permukaan air laut menjadi lebih panas. Besarnya angin yang bertiup juga mengakibatkan adanya forced convection dimana aliran angin menyebabkan temperatur permukaan menjadi lebih dingin karena adanya perpindahan panas sehingga energi yang di emisikan menjadi lebih dingin. Perbedaan temperatur antara perhitungan dengan pengukuran dilapangan disebabkan adanya perbedaan temperatur lingkungan sekitar permukaan, bisa saja citra satelit di ambil pada saat cahaya matahari tidak bersinar terik karena pada saat pengambilan data cuaca dalam keadaan cerah dan matahari bersinar terik dan angin bertiup lebih kencang pada saat pengambilan citra satelit daripada pada saat pengukuran di lapangan.

Perbedaan temperatur tersebut juga bisa disebabkan adanya human error pada saat pengambilan data karena meskipun sensor pengukur pada termometer telah diberi pemberat tetapi tetap kalah dengan gaya yang ditimbulkan oleh gelombang dan goncangan kapal sehingga posisi sensor tidak selalu tetap sehingga menghasilkan pengukuran yang random.

Atmosfer mengandung molekul gas dan partikel aerosol, debu dan asap yang menimbulkan scattering dan absorpsi. Scatering menyebabkan perubahan arah dan intensitas radiasi elektromagnetik. Absorbsi radiasi elektromagnetik oleh molekulmolekul gas yang terdapat pada atmosfer khususnya air $\left(\mathrm{H}_{2} \mathrm{O}\right)$, karbon dioksida $\left(\mathrm{CO}_{2}\right)$, oksigen $\left(\mathrm{O}_{2}\right)$ dan ozon $\left(\mathrm{O}_{3}\right)$ menyebabkan radiasi elektromagnetik akan berkurang atau bahkan hilang. Adanya perubahan energi elektromagnetik menyebabkan sensor tidak bisa menerima energi radiasi elektromagnetik sebanyak radiasi yang dipancarkan oleh permukaan bumi sehingga informasi yang terkandung pada radiasi elektromagnetik tidak sama persis dengan kondisi di lapangan.

Energi elektromagnetik yang diterima oleh sensor termal adalah energi yang dipancarkan oleh permukaan air laut sedangkan yang di ukur merupakan energi kinetik dari permukaan air laut dan energi yang dipancarkan selalu lebih kecil daripada energi kinetiknya. AVHRR mampu mengukur temperatur permukaan air laut hanya dengan mempunyai selisih rata-rata sebesar $0,9886^{\circ} \mathrm{C}$ daripada temperatur sebenarnya di lapangan. Ini karena AVHRR mempunyai tiga band yang bekerja pada kisaran inframerah termal, bila data citra di ambil pada siang hari maka perhitungan temperatur menggunakan band 4 dan band 5 tetapi bila pengambilan citra dilakukan pada malam hari penghitungan temperatur juga menggunakan band 3, hal ini dilakukan untuk koreksi atmosfer sehingga hasil yang didapat adalah temperatur permukaan air laut setelah proses koreksi atmosfer. Tiga band inframerah termal pada AVHRR yaitu band $3(3,5-5,5 \mu \mathrm{m})$, band $4(10,5-11,3 \mu \mathrm{m})$ dan band $5(11,5-12,5 \mu \mathrm{m})$ menurut Estes dan Holz, 1985; Sabins Jr., 1978 dalam Sutanto, 1994, pada panjang gelombang tersebut hambatan atmosfer relatif kecil sehingga tenaga termal dapat melaluinya 
dan berdasarkan hukum pergeseran Wien serta dilihat dari kurva distribusi spectral tenaga yang dipancarkan dari benda hitam pada pelbagai suhu tampak bahwa pada panjang gelombang 3,5-14 $\mu \mathrm{m}$ temperatur permukaan bumi mengalami pancaran paling maksimum dan puncaknya pada 9,7 $\mu \mathrm{m}$, tiga band AVHRR juga bekerja pada kisaran pada saat temperatur permukaan bumi mengalami pancaran maksimum.

Posisi satelit dan posisi matahari pada objek yang di indera juga mempunyai peranan yang cukup besar. Posisi satelit yang baik dan permukaan bumi yang cukup banyak mendapat radiasi matahari akan menghasilkan data citra yang lebih baik, karena mampu memancarkan radiasi elektromagnetik lebih banyak sehingga informasi yang dibawa oleh energi elektromagnetik lebih banyak.

\section{SIMPULAN}

Setelah diadakan analisis terhadap hasil perhitungan dengan persamaan MCSTT split-window dengan hasil pengukuran di lapangan di wilayah laut Tuban pada $6,83099^{\circ}-6,76149^{\circ}$ LS dan $112,029^{\circ}-$ $112,101^{\circ}$ BT maka dapat diambil kesimpulan sebagai berikut :

1. Satelit NOAA dengan sensor AVHRR mempunyai kepekaan yang tinggi dalam mengukur temperatur permukaan air laut karena selisih temperatur dari citra satelit dengan pengukuran di lapangan hanya memilki selisih ratarata $0,9886{ }^{\circ} \mathrm{C}$.

2. Temperatur permukaan air laut banyak di pengaruhi oleh temperatur lingkungan sekitar, kondisi cuaca, curah cahaya matahari, dan aliran angin yang menyebabkan terjadinya forced convection.

Dari hasil penelitian ini, penulis memberikan saran untuk bahan pertimbangan bagi yang akan melakukan penelitian dalam bidang penginderaan jauh terutama dalam hal temperatur permukaan air laut yaitu :

1. Sebelum melaksanakan survey lapangan hendaknya segala peralatan dan perlengkapan yang akan digunakan dalam survey telah dipersiapan secara matang serta mempelajari cara kerja peralatan yang akan dipergunakan misalnya mempelajari dengan baik cara kerja GPS dan thermometer yang akan digunakan.

2. Mengetahui sampai seberapa kedalaman dari permukaan yang akan diukur temperaturnya.

3. Memperhatikan kondisi lapangan karena hal ini mempunyai banyak pengaruh pada temperatur permukaan air laut pada saat pengukuran.

4. Melindungi peralatan yang digunakan jangan sampai terkena air laut karena air laut mempunyai sifat korosi.

\section{DAFTAR PUSTAKA}

[1] Brunsveld van Hulten, H.W., Hoogeboom, P.,Jacobs,A.F.G.,Kraan,C.,de Loor,G.P., Wartena, L., Communications Contributions to Remote sensing: Applications of Thermal Infrared, rijkswaterstaat, 1984.

[2] Cracknell, Arthur P., Remote Sensing Applications in Marine Science and Technology, Taylor\&Francis, London, 1982.

[3] Cracknell, Arthur P., The Advanced Very High Resolution Radiometer (AVHRR), Taylor\&Francis, London, 1997.

[4] CPLO, Bambang Purbowaseso, Penginderaan Jauh Terapan, Penerbit Universitas Indonesia, Jakarta, 1996.

[5] Jensen, John R., Introductory Digital Image Processing A Remote Sensing Prespetive Second Edition, Prentice Hall, Upper Saddle River, New Jersey 07458, 1996.

[6] Lillesand, Thomas M., Kiefer, Ralph W., Remote, Penginderaan Jauh dan Interpretasi Citra, Gadjah Mada University Press, Yogyakarta, 1990.

[7] Sutanto, Penginderaan jauh Jilid 1, Gadjah Mada University Press, Yogyakarta, 1994. 
[8] Sutanto, Penginderaan jauh Jilid 2, Gadjah Mada University Press, Yogyakarta, 1994.

[9] www.ccrs.com

[10] www.srrb.noaa.gov/highlight/sunrise/a ze!htm

[11] http://eoweb.dlr.de:8080/short guide/D -SST.html

[12] www.beareu.com

[13] http://rsd.gsfc.nasa.gov/rsd/RemoteSensing html 